\title{
The role of Islamic social finance towards alleviating the humanitarian crisis in North-East Nigeria
}

\author{
Ibrahim Mohammed Lawal*; Jiddah. M.A Ajayi \\ Department of Economics, Faculty of Social Sciences, University of Maiduguri Bama \\ Road, Maiduguri, Borno State, Nigeria \\ *To whom correspondence should be addressed. Email: ibrahimruqqy@gmail.com
}

\begin{abstract}
This paper seeks to examine the role of Islamic social finance towards alleviating the humanitarian crisis in North East Nigeria. The paper revealed the various conceptual definitions of Islamic social finance, its various instruments, update on humanitarian situation. A modified revenue function model was adopted. The study revealed that zakat potentials in Nigeria is estimated to be between USD 8,776.5-USD 21,160.99 million which is alone adequate to fill the humanitarian funding gap. More so, Sadaqah and Waqf was analyzed based on the number of active Telecoms line subscribers and the population statistics of citizens within the ages of 15-69yrs and that If N20 is paid weekly at a 5\% level of cash collection error rate, a total amount of about N162b and N106b could be realized yearly respectively which can be used to bridge certain sectors of humanitarian needs in areas of housing, primary health care centres, water, food, empowerment etc. Likewise, the said funds can still be used for investment purposes in areas like mudaraba term deposit, sukuk, stock etc most especially funds realized from cash waqf. The study concluded that by adequately combining the Islamic social finance tools while adopting technology in its collection process \& monitoring, it will effectively bridge the humanitarian funding gap as well as resettling and empowering the IDPs. The study recommends legislation of act setting up zakat/waqf, public awareness should be properly done, use of crowd funding approach.
\end{abstract}

Keywords: Islamic social finance, Internally displaced persons, Zakat, Waqf, Sadaqah, Humanitarian

JEL Classification: G23, P40, I31

\section{INTRODUCTION}

"The culture and traditions of Islamic giving has been and continues to be a crucial element in dealing with global humanitarian needs. People in the Islamic world have been extremely generous despite the poor economic conditions in many countries in the Islamic world" (Madani, 2016).

Nigeria is made up of six (6) geo-political zones namely; North West, North East, North Central, South East, South West and South South. The North East comprises of six (6) states; Adamawa, Bauchi, Borno, Gombe Taraba and Yobe state. The region is faced with high level insecurity which is attributed to a group called Boko Haram that emanated from Borno state. Boko Haram is a nickname that was labeled to a militant group which in Hausa means "Western education is a sin", is a jihadist militant 
organization based in the northeast of Nigeria, North Cameroon and Niger. The group original name is "Congregation and People of Tradition for Proselytism and Jihad" (Jama'a Ahl al-sunnah li-da'wa wa al-jihad). It is an Islamist movement which strongly opposes man-made laws and Westernization. It was founded by Mohammed Yusuf (Wikipedia, 2017).

This was a movement that started in 2001 but later gained momentum. The inability of the government to proactively contained the group at their early stage lead to the crisis in 2009. This crisis spilled over most of the states within and outside the north east states. Worse hit by the insurgents was Borno, Yobe and Adamawa states which resulted to the death of about 20,000 citizens, over $1 \mathrm{M}$ displaced persons and property (ies) worth USD5.9billion were lost (BOSG Report, 2016).

However, the effect of the crisis is multidimensional such as economic, political, socio-economic effect on the north east economy. From the economic view point; it has crippled the economic (business) activities within the areas, inflation is on the increase due to supply deficit, food insecurity, lack of investments, declining state revenue and lack of improvement in infrastructural development etc. The socio-economic implications is that it has lead to increase in crime rate, destruction in the population structure, unemployment, migration, illiteracy rate etc. Also, the political implication is that citizens were disenfranchised during election, political killings under the guise of insurgency etc.

Consequently, these activities of the insurgents have expose about 7.7 million people which are now in need of life-savings assistance which about $3.7 \mathrm{million}$ are food insecure (FOA,2017; OCHA,2018), 1.8 million people are internally displaced persons (IDPs) out of which $80 \%$ are from Borno state, the epicenter of the crisis and over $60 \%$ are living in host communities. With a IDPs figure of 1.8 million, the region is now considered third position globally after Syria and Afghanistan (Economic Confidential, 2016). The worrisome part of this insurgency is the increase number of internally displaced persons which are mostly women and children accompanied with different illness.

These situations have attracted the attention of both Government and NonGovernmental Organization within and outside the region because the host government and its facilities are overstretched; they have limited resources and their negligence to utilize their existing enabling environment like Borno State Zakat and Endowment Board Law, 2001 and Yobe State Religious Affairs Board 2001 to raise the required funds. However, to alleviate the sufferings of 6.1 million people in dire need of lifesavings aid in Borno, Adamawa and Yobe, the United Nations and Partners appealed for USD1.05billion for 176 projects to be implemented by 60 humanitarian organizations. This is considered as the sixth largest single-country appeal globally. According to the Financial Tracking Service (FTS), USD504million which is about 48.1 percent of the funds have been received, thereby creating a funding gap of 51.9 percent which is about USD546million. Major donors were from USA, UK, European Commission, Canada, Norway, Swedan, Netherland etc.

In lieu of this funding gap, the Nigerian Government setup the Nigeria Humanitarian Fund (NHF), one of the world's 18 country based pooled funds, with a target of USD100 million has raised USD63 million, including USD19.7 million in 2018 (OCHA,2018). With all these efforts, there is still a funding gap, thus the need to bridge this vacuum. This scenario calls for an alternative source of funding. Hence, the need for a financing option called 'Islamic Social Financing' or 'Social and faith-based financing'. Islamic Social Finance, are important additional sources of financing that 
can be better leveraged to reduce vulnerability and humanitarian crisis. Every year, Muslims worldwide donate generously to Islamic Social Finance mechanisms to alleviate human suffering (World Humanitarian Summit, 2016). It is against this background that this paper was carried out.

\section{LITERATURE REVIEW}

\section{Conceptual review}

Social finance

Social finance is an approach in investing and managing a certain fund with the purpose of solving societal challenges (MaRS, 2016). Social finance is defined as provision of financial services to achieve social protection of the poor; reduction in their vulnerability through community, microfinance, social enterprise finance, outcomebased philanthropic grant-making and program-related investments (Islamic Social Finance Report,2015; Aliyu Dahiru et al, 2018).

\section{Islamic finance}

Kammar et al (2015) sees Islamic finance as the provision of financial services in accordance with the Islamic jurisprudence (Shariah). Tabash and Dhankar (2014) defined Islamic finance as structuring financial instruments and financial transactions to satisfy traditional Muslim structures against the payment of interest and engaging in gambling. Similarly, the Falex Financial Dictionary (2012) sees Islamic finance as the range of financial transaction that conforms to the shariah or Islamic law.

\section{Islamic social finance}

Islamic social finance therefore refers to the provision of financial services to the vulnerable members of the society to achieve socio-economic welfare. It comprises three main sectors vis-à-vis zakat/sadaqah, waqf and Islamic microfinance. The institutions are meant to serve as platforms for empowering and disbursing wealth and income in the society.

\section{Instruments of Islamic social finance}

According to maiden Islamic Social Finance Report (2014) sector comprises the traditional Islamic institutions based on philanthropy-zakat, sadaqah, and waqf; those on mutual cooperation such as qard (loan) and kafala (guarantee); and also, the contemporary Islamic not-for-profit microfinance that use for profit modes to cover primarily their cost and sustain their operations

\section{Zakah}

Zakah or alms tax can be defined as that portion of a man's wealth which is designated for the poor. The word is derived from the Arabic verbal root meaning "to increase" "to purify" and to bless. Zakat is considered as the fourth pillars of Islam. It's a word that is associated with salat in eighty (82) quranic verses. Allah (SWT) and his messenger (PBUH) has enjoined upon us to give zakah.

Zakat seems to have a very specific purpose and remains obligatory to the community and any avoidance attracts a very strong penalty. However, it is pertinent to note that zakah has been practiced by past prophets. For instance Q19:31-By Prophet Jesus; Q19:55-Prophet Ishmael ordained on his people; Q2:83-Children of Israel; Q21:73-Prophet Abraham etc.

Allah (SWT) has instructed Muslims to pay zakah in the following verses Q2:43 “ And Establish the prayer; give Zakah.........so also in Q9:71,103, 104,Q22:41 etc. also there are different hadiths by the prophets enjoining Muslims faithfuls to pay zakat 
while stressing its importance. For instance "Abu Hurairah narrated that the prophet said" when you pay the zakat you have fulfilled what is required of you. ${ }^{1}$

Zakat rate enjoined upon Muslims to pay is $2.5 \%$ or $1 / 40$ (though the rich can be charged extra if what is realized is not enough to reduce poverty) which is usually paid once a year (Islamic year) and it should be paid on any amount of money remaining after meeting the expenses. The recipient of zakat is clearly stated in the holy Quran (9:60). "the alms are only for the poor and the needy, for those who collects them, for whose heart are to be reconciled, for the freedom of those who are captives and in debt, for the cause of Allah (SWT) and for the wayfarers. In addition, those people that are forbidden to receive zakah are the unbelievers and atheist, Banu Hashim Father, Sons and the wife.

Having established its permissibility in Islam we shall consider its relevance in the Christianity. The bible states "At the end of every third year you shall bring out all the tithe of your produce in that year, and shall deposit it in your town" (Deu 14:28). Also Gen 14:19-20 "Blesssed be Abram by God Most High, Possessor of heaven and earth; and blessed be God Most High, who has delivered your enemies into your hand!' And Abram gave him a tenth of everything. Similar verses are Gen.28:20-22, Lev 27:30-34 etc. Technically, this reveals that Zakat is also permissible in Christianity.

\section{Sadaqah or infaq fi sabilillah}

Sadaqah linguistically is derived from the root verb $s a d q$ or $s i d q$ which means to speak the truth, to be sincere. Sadaqah is a term applicable to the concept gift offered to someone from ones rightfully owned holding without remorse or regret or without any ulterior motives in secret for the pleasure of Allah. Thus, it involves the following ingredients; legitimacy of one's holdings, sincerity of intention, ultrusiun motives and the condition that it is for Allah. Allah (SWT) has enjoined his entire ummah to perform sadaqah in Q58:13, Q2:271, 262, 263. Sadaqah is not limited to monetary aspect alone, non monetary aspect is also welcome. However, the Holy Quran has stipulated who sadaqah is meant for especially in Q9:69, Q2:273 etc just as the case of zakat.

Sadaqah is considered as a means of purification, cleansing, redemption, atonement for sin as stipulated in the following verses Q9:103, Q2:196, Q2:271, Q2:280, Q5:5:45,Q2:72, Q2:267, Q30:39, Q12:88, Q64:16, Q663:10, Q57:18 and Q4:114 etc. The use of this instruments is also permissible in Christianity as obtained in the following verses; Proverb 19:17 which states that" One who is gracious to a poor man lends to the LORD, and he will repay him for his deed" and also such act is rewarding as stated in Matt 19:21 that" Jesus said to him, if you wish to be complete, go and sell your possession and give it to the poor, and you will have treasure in heaven; and come, follow me”. Similar verses can be found in Isiah 58:7, Matt 5:42, 25:35, Luke 14:13, 18:22 etc.

\section{Qard al hassan loan}

This is also called Good Loan, benevolent loan. It is considered as a type of loan whereby the lender does not charge any interest or additional amount over the money lent. Most of the existing micro credit (loan) availed to beneficiaries by the government via its micro finance banks are interest based. Despite a reduction in its interest element to single digit in as far as its not zero.

\footnotetext{
${ }^{1}$ Different narrations on the same subject can also be found in Sahih Al Bukhari Vol2, Book 2 (Obligatory Charity Tax-Zakat, No.702-765 and also At- Tirmidhi Vol2,Book 2, No.617-681 etc.
} 
Interest on loans as clearly spelt out in the Quran is prohibited as stated 12 different verses of the Quran. For instance Q2:275, Q 2:278 so also there are different hadiths that prohibits interest in all its forms. Therefore, non compliance to Allah's command, make such funds to lacks his blessing. Interest on loan has the following effects, it's a repression of the needy, it further widen the distribution of wealth, it creates inflationary tendencies, its an unjust income, its markdown the future, it causes economic volatility.

\section{Waqf}

Waqf is an Arabic word derived from a root verb waqafa. Its plural is awqaf. It refers to an Islamic endowment of property to be held in trust and used for a charitable or religious purpose. Waqf is made up of different kinds (Kafh, 2007).

Religious Waqf:-This form of waqf serves as an addition to the social welfare of any society as it assist to satisfy the religious needs of the people and thus reduce the direct cost of providing religious services.

Philanthropic Waqf: This form of waqf is targeted at supporting the poor in the society such as providing public utilities for the needy or poor such as libraries, education, health services etc.

Posterity or Family Waqf: In this form waqf the revenue must be given to the waqf founder and his or her descendents and only the surplus if any should be given to the poor.

However, a new form of waqf called cash waqf and waqf of intellectual property has been the order of the day. Cash waqf:- This form of cash serves as a waqf instead of the popular building or land. It is very flexible and thus allows distribution to the poor anywhere. This was first introduced in Othman era in Egypt. Whereas the Waqf of intellectual property:-this consists of copyrights of books.

Waqf has certain distinct features such as:- Perpetuity:- This implies that once a property is decided as waqf so shall it be and the condition specified by the waqf founder must be followed in as far as it does violate shariah.

Furthermore, waqf has two beneficiaries-family members and the general society. The latter is very relevant towards poverty alleviation. For instance, waqf via schools, hospitals etc students and patients attends at little or no cost. This will aid the development of human capital which invariably creates a productive workforce, thus assisting in poverty alleviation because with a productive workforce, GDP will increase, unemployment will decrease so also income inequality gap will be bridged.

Although the Holy Quran does not directly define waqf or make any particular reference to it, however, it encourages Muslim to perform charity and donation. Allah has promised multiple rewards for those who generously spend their wealth in his path (Mohammed, 2014). This is supported by the following verses; "They ask you what they should spend.Say: Whatever you spend of good must be for parents and kindred and orphans and al-masakin (poor) and the wayfarer and whatever you do of good deeds, truly Allah knows it well (Q2:215)". Related verses can also be seen obtained in Q2: 254, 270 and 280.

In a similar view, there are hadiths which further supports waqf. Abu Hurairah reported Allah's messenger as saying: When a man dies, all his acts come to an end, but three: recurring charity, or knowledge (by which people benefit), or a pious offspring, who prays for him" .2

\footnotetext{
${ }^{2}$ Muslim, 1992: bab3, hadith 14.
} 
However, the concept of waqf is not entirely new to the non-Muslims as well because it has been practiced non-Muslims during the Ottoman period (Shaham, 1991; Azniza \& Mohamed,2015). Though, several verses of the bible have stressed the need for charity such as Hebrew 13:16, proverbs 19:17, II Corinthians 9:7 etc. Therefore, based on the submission given, we can explicitly deduce that waqf is permissible for Muslims and non Muslims. Having discussed the instruments of Islamic Social Finance, it is pertinent to present a snapshot of the Humanitarian situation in the North East Region.

\section{RESULTS AND DISCUSSION}

\section{Humanitarian situation update in North East Region}

In order to present a snap shot of the humanitarian situation up in the North East region of Nigeria, we shall consider some key areas; Food Security, Protection, Health, Nutrition, Shelter and Non-Food items, Education and Water, Sanitation and Hygiene (WASH).

Table 1. Humanitarian performance snap-shot as at 2018

\begin{tabular}{|c|c|c|c|c|c|c|c|}
\hline \multirow[b]{2}{*}{ Area } & \multirow{2}{*}{$\begin{array}{l}\text { People in } \\
\text { need }\end{array}$} & \multirow{2}{*}{$\begin{array}{c}\text { People } \\
\text { nargeted }\end{array}$} & \multirow{2}{*}{$\begin{array}{l}\text { People } \\
\text { reached }\end{array}$} & \multicolumn{3}{|c|}{$\begin{array}{c}\text { Breakdown of people reached by } \\
\text { category }\end{array}$} & \multirow{2}{*}{$\begin{array}{c}\text { Funding } \\
\text { coverage } \\
(\%)\end{array}$} \\
\hline & & & & Displaced & Returnee & $\begin{array}{c}\text { Remaining } \\
\text { people in } \\
\text { need }\end{array}$ & \\
\hline Food security & $3,700,000$ & $3,700,000$ & $3,105,058$ & $1,356,539$ & 616,782 & $1,131,737$ & 45.40 \\
\hline Protection & $5,800,000$ & $2,700,000$ & $1,619,259$ & $1,097,182$ & 120,880 & 319,408 & 13.50 \\
\hline Health & $5,400,000$ & $5,100,000$ & $2,631,792$ & 490,304 & 37,173 & $2,104,315$ & 24.5 \\
\hline Nutrition & $3,500,000$ & $2,700,000$ & 893,597 & 161,524 & 153,117 & 578,956 & 66.4 \\
\hline $\begin{array}{l}\text { Shelter \& non- } \\
\text { food item }\end{array}$ & $2,100,000$ & $1,300,000$ & 152,513 & 70,188 & 0 & 82,325 & 11.8 \\
\hline Education & $2,800,000$ & $2,200,000$ & 110,297 & 25,147 & 12,664 & 72,486 & 10.8 \\
\hline WASH & $2,900,000$ & $2,100,000$ & $2,315,139$ & $1,331,136$ & 75,281 & 908,772 & 20.1 \\
\hline
\end{tabular}

From the Table 1, all the sectors could not achieve 100\% of its target. Funding could be the key reasons because apart from Nutrition which has a funding coverage of $66 \%$, all the sectors have funding coverage less than 50 percent. By and large, certain progress has been achieved so far, thus the need to sustain and improve on the performance.

\section{Potentials of Islamic social finance tools towards alleviating humanitarian crisis in North East Nigeria.}

In order to discuss this section, we shall explain it alongside with the various instruments of Islamic Social Finance.

\section{Zakat}

According to the IDB's research institute, global Zakat collections alone are estimated to come up to a total of at least US $\$ 500$ billion a year. This is about 20 times more than total global humanitarian aid (GlobalSadaqa Beta,2018). Despite the fact that there are no reliable data currently to depict accurately how much zakat is being paid by Muslims around the world and how much is spent. However, a beautiful system of Zakat alone should be sufficient to alleviate the global humanitarian crises which Nigeria and North East region is not an exception.

More so, previous estimates have revealed that USD200 to USD I trillion is spent from Islamic charitable giving (zakat) every year in Muslim Countries. This further 
place zakat within the 10 highest donors (Majis \& Amma,2016). In Nigeria, the potential of zakat in 2013 is estimated to be between $0.86-2.08 \%$ of GDP or USD 8,776.5-USD 21,160.99 million (IRTI-Islamic Social Finance Report, 2015; Aliyu Dahiru et al, 2018). This amount realized is sufficient to get rid of the funding gap identified in Food Security, Protection, Health, Nutrition, Shelter \& Non-Food items, Education \& Water, Sanitation \& Hygiene; thereby alleviating the humanitarian crisis in the country.

Table 2. Summary of humanitarian funding gap

\begin{tabular}{lccccc}
\hline \multicolumn{1}{c}{ Area } & $\begin{array}{c}\text { People in } \\
\text { need }\end{array}$ & $\begin{array}{c}\text { Remaining } \\
\text { people in } \\
\text { need }\end{array}$ & $\begin{array}{c}\text { Funds } \\
\text { budgeted } \\
\text { (\$million) }\end{array}$ & $\begin{array}{c}\text { Funds } \\
\text { received } \\
\text { (\$million) }\end{array}$ & $\begin{array}{c}\text { Funds } \\
\text { unmet } \\
\text { (\$million) }\end{array}$ \\
\hline Food Security & $3,700,000$ & $1,131,737$ & 435.1 & 197.3 & 237.8 \\
Protection & $5,800,000$ & 319,408 & 113.7 & 15.3 & 98.4 \\
Health & $5,400,000$ & $2,104,315$ & 109.6 & 26.8 & 82.8 \\
Nutrition & $3,500,000$ & 578,956 & 107.1 & 71.1 & 36 \\
Shelter \& Non-Food item & $2,100,000$ & 82,325 & 67.4 & 7.9 & 59.5 \\
Education & $2,800,000$ & 72,486 & 60.9 & 6.6 & 54.3 \\
WASH & $2,900,000$ & 908,772 & 48.7 & 9.8 & 38.9 \\
\hline
\end{tabular}

Source: OCHA, 2018

Relating the estimated sum of the funding gap of over USD 600 million (N183 billion@N305-\$1) to the potentials of zakat that have a minimum \& maximum value of USD 8,776.5-USD 21,160.99 million, it is obvious that the zakat can be used alone successfully to curb the humanitarian crisis without reverting to other instruments of Islamic Social Finance. To actualize this potential and to minimize the issues faced in zakat management system such as transparency \& accountability/corruption issues, ineffective collection mechanism and skeptism on the part of contributors regarding distribution impact etc, hence the need to adopt an innovative approach called Crowd funding. It is the practice of funding a project or venture by raising small amounts of money from a large number of people, typically from the internet (Wikipedia,2018).

Crowd funding is not a new concept and the largest platforms move billions of dollars every quarter. Most importantly, Crowd funding provides platforms that are transparent and with progress updates on campaigns - features which are clearly needed to improve the traditional Islamic social finance system. Crowd funding has been highly successful in non-Muslim jurisdictions such as the US, Europe and China. In 2015, a worldwide estimate totaling USD34 billion was raised via crowd funding (Wikipedia, 2018).

Islamic crowd funding, on the other hand, has only started to gain momentum, with a handful of Islamic crowd funding platforms starting to generate considerable traction and impact. Some of the selected examples of newly emerged Islamic social enhance crowd funding platforms include Humancrescent.org and GlobalSadaqah.com, among others (GlobalSadaqah, 2018).

\section{Sadaqah}

Sadaqah also can also be a contributory tool in curbing the humanitarian crisis in the region. Though, despite its status as voluntary and not a compulsory act, it is considered as a cogent pillar in Islamic Social finance. For the purpose of this study, we shall demonstrate its potentials in terms of cash basis.

To buttress this argument of cash sadaqah potentials, a projected cash flow is further conducted. A simple revenue function $\left(\mathrm{P}^{*} \mathrm{Q}\right)$ is adopted and modified. (i.e Price $\mathrm{X}$ Quantity) as thus; $\mathrm{T}=\mathrm{S}_{\mathrm{A}} *$ Pop. Where T: Total cash generated, $\mathrm{S}_{\mathrm{A}}$ : Sadaqah amount 
voluntarily contributed per individual active lines; Pop: Total Population of active lines. Therefore, relating the works of Mohd, et al (2012) to the Nigeria case with a total population of active lines of about 164,865,417. This estimation is done under the following assumptions: a) It will consider only population of active line users; b) Every citizen voluntarily in respective of religion contributes a minimum of N20 per week; c) Payment can be spread with the week for individual lines with sufficient airtime; d) No carryover of payment to another week; e) $5 \%$ level of cash collection error rate (i.e. some remain uncollected, some did not pay in full, some lines went inactive or dormant and some paid above N20 etc) is considered; f) Use of existing structure and facilities of government/mobile operators; g) Sadaqah funds are to be managed by prudent and efficient trustees; h) Provision for lump sum payment (i.e, one off on per monthly); i) All active lines will be considered on case by case basis; j) $10 \%$ proceeds should be considered as administrative expenses.

Table 3. Projected cash inflows (active lines)

\begin{tabular}{lcc}
\hline Descriptions & $\begin{array}{c}\text { Cash Sadaqah of N20 } \\
\text { per week (NGN) }\end{array}$ & $\begin{array}{c}\text { Assume if 5\% error rate } \\
\text { (NGN) }\end{array}$ \\
\hline Total cash realised per week & $3,297,308,340$ & $3,132,442,923$ \\
Total cash realised per month & $13,189,233,360$ & $12,529,771,692$ \\
Total cash per annum $(52 \mathrm{wks})$ & $171,460,033,680$ & $162,887,031,996$ \\
\hline
\end{tabular}

Source: Authors Computation, (2019)-For Research Purpose

Based on this stream of income generated from sadaqah in Table 3, it could cater for the IDPs in the following areas as presented in Table 4 as thus:

Table 4. Projected expenditure(s)

\begin{tabular}{|c|c|c|c|c|}
\hline $\mathbf{S} / \mathbf{N}$ & Sector & Location & $\begin{array}{l}\text { Estimated unit } \\
\text { cost }\end{array}$ & $\begin{array}{l}\text { Estimated total } \\
\text { cost }\end{array}$ \\
\hline 1 & Health (PHC) & $\begin{array}{l}5 \text { units of PHC each in 65 LGA's } \\
\text { of Adamawa, Borno \& Yobe) }\end{array}$ & $29,115,628.36^{* * * *}$ & $28,387,737,651$ \\
\hline 2 & Housing (2-Bedroom) & 3 States (2,000 Units) & $3,029,400 * *$ & $18,176,400,000$ \\
\hline 3 & Water (Boreholes) & $\begin{array}{l}5 \text { each per polling units out of the } \\
8,255 \text { PU in Borno, Adamawa \& } \\
\text { Yola) }\end{array}$ & $575,000 *$ & $28,479,750,000$ \\
\hline & & & Total & $\mathbf{7 5 , 0 4 3 , 8 8 7 , 6 5 1}$ \\
\hline
\end{tabular}

The Table 4 depicts that in its first year of adoption, funds to be realized can be able to build about 975 Primary Health Care (PHC) centers spread across the LGAs across in the Borno, Adamawa \& Yola with an estimated cost of N28b. In the housing sector, part of the funds can also be used to build about 6000 housing units across the Borno, Adamawa \& Yola (2-bedroom apartments) at the cost of N18b so also same funds can be used in the provision of about 49,530 boreholes spread across the polling units in Borno, Adamawa \& Yola with a total cost of N28b.

Furthermore, after these expenditures, part of the funds can be invested so as to sustain the performance and empowerment program/ capacity building programs thereby making the affected persons to be independent and productive. If this tempo can be sustained for a period of 1-5years on the identified sectors, it can go a long way to resettle the internally displaced persons and returnees in the North east especially Borno Yobe and Adamawa to their various localities, thus alleviating the humanitarian crisis. 


\section{Waqf}

Waqf is driven by spirituality, social justice, and personal satisfaction of the donors and it is purposely meant to provide key essential services like health, education etc so as to improve the welfare of the people in the society at no cost. This was evidenced during the Ottoman Empire in which the waqf was incorporated in its fiscal system to cater for its public expenditures for decades. In addition, prophet Muhammad (Pbuh) also used waqf to finance for weaponry in times of war via the fruits from Orchards left by Mukhayriq and well as financing the economy (Siddiqi,1995). This reasons for the background of waqf, formed the justification, the argument of bridging infrastructural deficit via waqf. The global size of waqf asset is estimated between USD105billion to USD1 trillion (SFC, 2017).

However, existing literatures like Cizakca (1998), Mohammed et al (2012), Kahf (1998) and Islahi (1992) have also been captured along such lines. Cizakça (1998), he stressed that economists looking at the waqf system would be perplexed by the fact that a myriad of essential services such as health, education, municipal, etc., have historically been provided at no cost whatsoever to the government. Therefore, ceteris paribus, the waqf system can contribute significantly towards that ultimate goal of so many modern economies as it leads to a massive reduction in government expenditure, freeing government funds to other sectors, with its attendant benefits of economic development.

However, for the purpose of clarity, this section will limit its discussion to the cash waqf, which refers to "the devotion of an amount of money by a founder and the dedication of its usufruct in perpetuity to the prescript purposes" (Magda Ismail, 2008). Relating the cash waqf model to the Nigeria case in ensuring bridging of funding gap, it consists of three major phases namely: the phase of cash collection rate, the in vestment phase and the implementation phase.

The first phase which is the cash collection rate is considered as the bedrock in which other phases are built upon. This has to do with how long it takes to mobilize these funds. This fund can be traced to the contribution from the general public which is usually voluntary in nature. This can be in physical cash or through other platforms like E-waqf funds which is deducted from their bank account or via mobile by sending coded SMS to a designated sever number ordering for deduction from his or her airtime. This is considered as the easiest means for the public to join Waqf scheme.

However, a key mitigating factor to the cash collection rate is population. However, available records have shown that Nigeria has a population of about $193 \mathrm{M}$ (NBS,2017) out of which $49.3 \%$ are Muslims, $48.8 \%$ are Christians while $1.9 \%$ traditional beliefs (Pew Survey, 2012). However, the main contributor would be from the Muslim faction of the population.

The second phase which is the investment phase has to do with investing the said waqf funds directly or indirectly. These can be via mudarabah deposit, sukuk (Islamic bond), Islamic mutual fund and shariah compliant stocks. Also, part of the funds or proceeds from such investment are either plough back or used at the last phase called the implementation phase. At this stage, the funds can be used four key purposes such as education, health, housing, social and community services so as to alleviate the humanitarian crisis..

In addition, to buttress the argument on cash waqf potentials, a projected cash flow is further conducted. Adopting same simple revenue function $\left(\mathrm{P}^{*} \mathrm{Q}\right)$ is adopted and modified. (i.e Price X Quantity) as thus; $\mathrm{T}=\mathrm{W}_{\mathrm{A}} *$ Pop. Where $\mathrm{T}$ : Total cash generated, 
$\mathrm{W}_{\mathrm{A}}$ : Waqf amount contributed per individual; Pop: Total Population. Therefore, relating the works of Moh'd, et al (2012) to the Nigeria case with a total population of about $193,392,517$ out of which 107,842,572 are within the age of 15-69years (NBS, 2017). Populations within this age bracket are considered as the active population. This estimation is done under the following assumptions: a) It will consider only population within the age bracket of 15-69 years; b) Every citizen in respective of religion contributes a minimum of N20 per week; c) $5 \%$ level of cash collection error rate (i.e. some remain uncollected, some did not pay in full, some individuals are dead, some underage later qualified within the age bracket and some paid above N20 etc) is considered; d) Use of existing structure and facilities of government; e) Waqfs are managed by prudent and efficient trustees; f) $10 \%$ to be considered as administrative expenses.

Table 5. Projected cash inflows (population)

\begin{tabular}{lcc}
\hline Descriptions & $\begin{array}{c}\text { Cash Waqf of N20 per } \\
\text { week (NGN) }\end{array}$ & $\begin{array}{c}\text { Assume if 5\% error rate } \\
\text { (NGN) }\end{array}$ \\
\hline Total cash realised per week & $2,156,851,440$ & $2,049,008,868$ \\
Total cash realised per month & $8,627,405,760$ & $8,196,035,472$ \\
Total cash per annum (52wks) & $112,156,274,880$ & $106,548,461,136$ \\
\hline
\end{tabular}

Source: Authors computation, (2018)-for research purpose

Table 5, shows the total cash waqf realized if Nigerians within the age bracket (15-69yrs) donate N20 per week. This is to generate about N2,049,008,868 and $\mathrm{N} 8,196,035,472$ and weekly and monthly respectively while total of N106,548,461,136 will be generated on yearly basis. And, in worst case scenario if only Muslims donates to the cash waqf, then it will be N53,274,230,568 which is approximately $50 \%$ of based on the available records on Muslim population. However, from the projected funds realized, if it can be judiciously invested in mudarabah deposit, the proposed income will be as thus:

Under this investment option, it is assumed that the Mudarabah term deposit rate is 5\%, Profit \& Loss ratio is 50:50 (Bank and the SPV). The Mudarabah calculator is adopted.

Table 6. Proposed investment of Waqf funds

\begin{tabular}{lcr}
\hline Duration of Waqf funds realised & $\begin{array}{c}\text { Amount invested } \\
\text { @ 90days }\end{array}$ & \multicolumn{1}{c}{ Profit earned } \\
\hline Total cash realised per week & $2,049,008,868$ & $12,757,185.35$ \\
Total cash realised per month & $8,196,035,472$ & $51,028,741.40$ \\
Total cash per annum (52wks) & $106,548,461,136$ & $663,373,638.17$ \\
\hline Source: http://www.bankislam.com.my/home/calculators/deposit-calculator-using-profit-sharing-ratio/.
\end{tabular}

From Table 6, the said funds earned from the profit of the investment can be channeled towards cushioning some of the humanitarian gap while the principal amount remained unspent. This could serve as a continuous stream of income towards bridging the deficit mostly especially in taking care of human capital development and empowerment.

\section{Management of Islamic social finance system}

Under this form of proposed Islamic Social finance system, Nigerians are considered as the founder whether it viewed based on individuals or active lines. As founders, they decide the purpose for which the funds will be expended for but in this case it is specifically to curb the humanitarian crisis in the North East region. This can 
be in education, health, housing, water provision, social and community services, etc in as far as it constitutes expenditure that is shariah compliant. Individuals can contribute any form of resources that are deemed beneficial and can indeed help finance to fill the humanitarian gap.

The Islamic Social finance system is to be headed by a learned and renowned cleric and its management team while the board will constitute members from the State and NGO's. i.e., representative from the Ministry of Finance, Internal Revenue Board, Central Bank of Nigeria, Ministry of Budget and Planning, Nigeria Communication Commission, National Population Commission, telecom operators and representatives from the various religions like Nigeria Supreme Council for Islamic affairs, Christian Association of Nigeria. The Islamic Social finance system should be centrally coordinated with a well decentralized structure at the state and local levels but must be independence from government interference. Though, it will be managed under the platform of North East Reconstruction, Rehabilitation and Resettlement Agency. The crowd funding platforms can also be used to support the collection process.

However, as trustees or mutawalli, these stakeholders must cooperate to carry out key responsibilities like; creating awareness and collection waqf/zakat/sadaqah contributions, ensuring that the funds are used only for the purposes assigned by the founders, ensure the protection of the rights for both Muslims and non-Muslims, as beneficiaries and monitor the investment are Shari'ah compliant. See a flow chart of the Islamic Social finance management system.

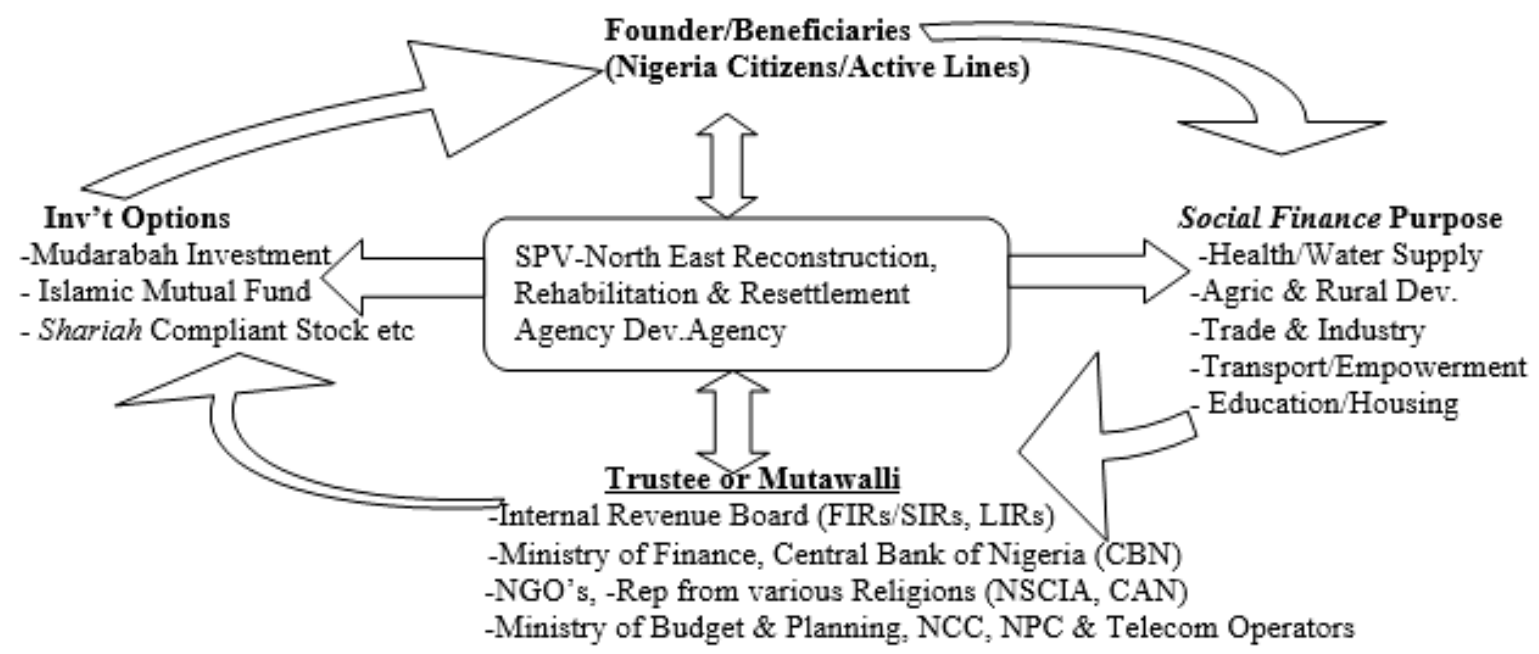

Figure 1. Flow Chart of Islamic Social Finance Management System

Source: Modified by Author from works of Azniza \& Mohamed (2015) -For Research Purpose

The founders who are also considered as beneficiaries, donate their contribution either as zakat, sadaqah and waqf. The funds contributed are then managed by the trustees under a Special Purpose Vehicle called- North East Reconstruction, Rehabilitation \& Resettlement Agency Dev.Agency. The agency will use part of funds contributed by the founders (Nigerian Citizens) for the purpose of filling the humanitarian gap as identified in Table 2 and also invest some funds in mudaraba investment, Sukuk, shariah compliant stocks etc. it is quite fundamental that such investment have to be shariah compliant. Consequently, the investment proceeds will then be used by the SPV towards assisting the beneficiaries. 


\section{Qard al hassan loan}

This type of loan can be disbursed to the IDPs which could serve as a source of empowerment or initial capital to commence a particular business after when they have been trained in one skills acquisition programmes. These funds will be disbursed out of the total amount mobilized and it will not be interest based. The seed capital to undertake this task can be utilized from the profit earned from the Mudarabah deposit investment.

\section{CONCLUSION AND RECOMMENDATIONS}

\section{Conclusion}

Nigeria most especially the North east states have never been faced with an insecurity situation that has taken long (over 9yrs) like this in history. This has continued to drain the region's resources, causes loss of lives and properties and has further resulted to a huge number of internally displaced persons (IDPs). In a bid to take care of this huge number of IDPs, it has over stretched the existing government facilities thus the need for intervention from NGOs. Though, their interventions was a welcomed one but they too are also constraint with resources considering the humanitarian situation been faced. This necessitates the need for an alternative source of financing. This is a system that been practiced since the time of the prophet (PBUH) and his followers and it is permissible to Muslims and non Muslims. Most countries like Malaysia, Kenya, Morocco, Sudan etc that are have adopted some of these tools in addressing the provision of essential facilities and eradicating of poverty at no cost to the government. Hence, Nigeria should not be an exception.

Therefore, the role of Islamic social finance tools to the current humanitarian crises been faced now especially in the north east states cannot be overemphasized as it will go a long way to assist in alleviating the crisis at no cost to the government without necessary overstretching them in all aspects. Consequently, this necessitate the need to welcome it as fiscal tools in order to aid the government in its governance process without any religious biasness so that the desired result can be achieved as the current humanitarian crises has no boundaries when it comes to religion or ethnicity.

\section{Policy recommendations}

Since these tools are permissible in shariah and has been practiced by nonmuslims in the past, there is need to intensify effort on public awareness in order to enlightened the Nigerian populace about benefits of waqf via local media like TV, radio in local dialects, magazines, articles etc as this will go a long way to address some of the misconceptions about some of this tools

There is the need to have a legal framework such as Zakat/Waqf Act or creation of ministry as this will ensure transparency as its record will be subject to public scrutiny. More so, the Zakat/Waqf Advisory Board need to be setup so as to moderate its financing activities in ensuring that the government expenditure to be financed should not be vague and non shariah compliance.

There was case of corruption associated with previous implementation of waqf/zakat. In lieu of that there is need to improve the welfare of the staff involved and also train and retrain them on task ahead of them.

Taking into play that cash collection rate goes a long way to determine the performance of these system, there is to deploy of IT equipments, portals so as to fasten waqf cash collection rate so easy and convenience. 
There is need to adopt a mix of financing tools so as to take care of the peculiarities that may exist and likewise Training, retraining and organizing development program for officers involved in the entire administration of waqf is highly required.

Ensuring that the zakat/waqf officers welfare are properly taken care off so as to avoid them tempering with the revenue generated and also Contracts for provision of infrastructural facilities to host communities should be awarded to their indigenes so that the community can know who to look up to incase whether the job is abandoned or done haphazardly.

The states like Borno, Yobe where relevant acts are already in existing which is not active, creates the need for it to be revisited in order meet best practices.

\section{REFERENCES}

Aliyu, D.H., Muhammad, L,M., Usman, B.S., (2018). The Role of Islamic Social Financing in Empowering Youth and Women in Sokoto State. Journal of Islamic Monetary Economics and Finance. 3. 141-152

Azniza, H A., \& Mohamed, A H. (2015), The Possible Role of Waqf in Ensuring A Sustainable Malaysian Federal Government Debt. Procedia Economics and Finance. Science Direct. 31, 333-345

Badeshi (2017). National Primary Health Care Development. Available at: www.budeshi.ng/\#menu>chooseadataset>NationalPrimaryHealthCareDevelopme nt. Retrieved on 29/09/2017.

BOSG Report(2016). Counting The cost of Insurgency. Post Insurgency Recovery \& Peace Building Assessment Report Presented by BOSG to World Bank. Available at;www.vangaurdngr.com/2016/03/borno-state-counting-the-cost-ofinsurgency/amp. Retrieved on 16/06/2017.

Building Contractors Secret (2017). What would it cost to build a standard 2 bedroom flat in Nigeria. Available at www.buildingcontractorssecrets.tk/2017/06/whatwould-it-cost-to-build-a-standard-2-bedroom-flat-in-nigeria.html?m=1 Retrieved on $28 / 092017$

Castle (2017). Cost of Boreholes ranges from N150k-N1,000,000 depending on location. Available at www.castle.com.ng/magazine/article/construction/ 67

Çizakça, M (1998). Awqaf in History and its Implications for Modern Islamic Economies. Islamic Economic Studies, . 6(1), 43-70.

Economic Confidential (2016).Dangote donates N2billion to Borno IDPs. Available at: https://economicconfidential.com/news/national-news/dangote-donates-n2bnborno-idps/amp/. Retrieved on 27/06/2017.

Falex Dictionary (2012). Islamic Finance. Available at: http://financialdictionary. Thefreedictionary/Islamic+finance. Retrieved July 30, 2015

FOA (2017). North Easten Nigeria. Situation Report. Food and Agriculture Organisation of United Nations. 1-2

Global Sadaqah Beta (2018).Crowdfunding: The Future of Islamic Social Finance? Available at:https://www.globalsadaqah.com/blog/crowdfunding-future-islamicsocial-finance/. Retrieved on 31/12/2018.

Islahi, Abdul Azim, (1992). Provision of Public Goods: Role of the Voluntary Sector (Waqf) In Islamic History. (Financing Development In Islam: Seminar proceeding series IRTI \& IDB)

Islamic Social Finance Report (2015). Islamic Research and Training Institute, Islamic Development Bank, Jeddah. 
Islamic Social Finance Report (2014). Islamic Research and Training Institute, Islamic Development Bank, Jeddah.

Kahf, M (2007).Role of Zakah and Awqaf in Reducing Poverty: A case for zakahawqaf-Based Institutional Setting of Micro Finance. Paper presented at the "International Seminar on "Islamic Alternative to Poverty Alleviation: Zakat,Awqaf and Micro Finance" April 21-23,2007, Bangladesh. In Foyasal, K, “ Waqf: An Islamic Instrument of Poverty Alleviation-Bangladesh Perspective. Thought on Economics. 22(3).

Kahf, ,M,(1998). Financing the Development of Awqaf Property. Working Paper for the Seminar on Development of Awqaf by IRTI, Malaysia. Kuala Lumpur

Kamar, A, Norat M, Pinon M, Prasad A, Towe C, Zeidaine, Z \& IMF Staff Team (2015). Islamic Finance: opportunities, Challenges and policy Options. IMF Staff Discussion Note :8-11\& 26

Madani, I (2016). Islamic Social Finance. Special Session Summary. Core Responsibility. Five of the Agenda for Humanity. World Humanitarian Summit. Istabul. 23-24. May, 2016.

Magda Ismail, A, (2008).Cash Waqf A New Financial Product Model Aspects Of Shariah Principles On ITS Commercialization, This paper is presented at Islamic Banking, Accounting and Finance Conference (iBAF 2008), organized by Faculty of Economics and Muamalat, Universiti Sains Islam Malaysia, 28-29 July 2008 at The Legend Hotel, Kuala Lumpur 2008

Majlis, E \& Amma, J (2016).Zakat for Humanitarian Aid and Development. Wana Institute. Available at:https://wanainstitute.org/sites/sites/default/files/projects/ WL-Zakat_For-Development.pdf

MaRS Centre for Impact Investing. (2016). Available at: http://impactinvesting.marsdd. com/ Retrieved on 31/12/2018.

Mohamed, U, Shahida, S, Abdul, G, \& Zaini, E. (2012). Tackling Poverty: A Look at Cash Waqf. Prosiding PERKEM VII,. 1611-1623.

NBS (2017).National Population Estimates. Available at: https://nigerianstat.gov.ng/ dowload/120. Retrieved 10/01/2019.

NCC (2018). Subscribers Statistics. Available at: https://www.ncc.gov.ng/ stakeholders/statistics-reports/subscribers-data. Retrieved on 10/01/2019.

OCHA (2018).North-East Nigeria; Humanitarian Situation Update. Progress on key activities from the 2018 Humanitarian Plan (Covering 1-31 $1^{\text {st }}$ July,2018). August Edition

Pew Research Center ,(2012). Religious Composition by Country in Percentages. Availableat:www.pewforum.org/2012/12/18table_religious_composition_by_cou ntry_in_percentage/Retrieved January05. Retrieved on 05 January 2016

SFC Report (2017). Social Financing: A Sharia Compliant Model. 13-22

Tabash I.M., and Dhankar R.(2014). Islamic Finance and Economic Growth: An Empirical Evidence from UAE. Journal of Emerging issues in Economic, Finance and Banking. 3(2), 1069- 1082.

Wikipedia. (2018). Crowd funding. Available at: https://en.wikipedia.org/wiki/ Crowdfunding.Retrieved on 10/01/2019.

Wikipedia (2017). Boko Haram. Available at: https://en.m.wikipedia.org/wiki/ Boko_Haram Retrieved on 30/09/2017.

World Humanitarian Summit (2016). Islamic Social Finance. Special Session Summary. Core Responsibility Five of the Agenda for Humanity. World Humanitarian Summit. Istabul. 23-24 May, 2016. 